\title{
Residents' Perceptions on the Effectiveness of Road Humps in Improving Malaysian Residential Environments
}

\author{
Khairun Sarah Radhiah binti Bachok, Abdul Azeez Kadar Hamsa, Mohd Zin Mohamed, \\ Mansor Ibrahim \\ International Islamic University Malaysia \\ Jalan Gombak, 50728 Kuala Lumpur, Malaysia \\ khairunsarah@gmail.com; azeez@iium.edu.my
}

\begin{abstract}
Two common concerns for residents in their respective residential areas are high traffic speeds and noise levels. This paper analyses if road humps are viable as a measure for improving residential living environment based on their effects on traffic speed and noise. The study was conducted in three Malaysian residential areas: Putrajaya, Taman Setiawangsa, and Keramat. A questionnaire survey was distributed to 478 respondents asking for their perception on whether road humps have improved the living environment by reducing speed and noise. Binary logistic regression models were also estimated using the questionnaire data regarding whether the existing road humps have improved the living environment by reducing traffic noise. Descriptive analysis was conducted to assess changes in average vehicle speeds and noise levels for the selected 12 road humps. The significance of this paper is that it explains the effect of existing Malaysian road humps on actual residential environments, which can potentially help improve the planning of new residential areas. The result of this study is that road humps are effective in reducing vehicle speeds but are not viable as a noise reduction measure.
\end{abstract}

Keywords: Malaysia, Residential, Road Hump, Vehicle Speed, Traffic Noise

\section{Introduction}

A standard issue in Malaysia is that road hump installations differ in dimensions, which previous literature has stated can lead to reduced effectiveness. This paper assesses the effects of different road hump configurations on the traffic noise levels and vehicle speeds; however, the main focus of this paper is on the residents' perceptions of road hump effectiveness. The field survey findings are also covered briefly to give a more comprehensive understanding of the existing conditions.

Studies conducted by Abbott, Taylor, and Layfield [1] and Bendtsen and Larsen [2] proved that road humps could reduce traffic noise levels by reducing vehicle speeds. Abbott, Taylor, and Layfield [1] stated that the installation of road humps reduced the average noise level from light vehicles by $3.9 \mathrm{~dB}(\mathrm{~A})$ midway and $8.2 \mathrm{~dB}(\mathrm{~A})$ alongside the hump, which corresponded with the speed reductions of $13 \mathrm{~km} / \mathrm{h}$ and $19 \mathrm{~km} / \mathrm{h}$ respectively. Bendtsen and Larsen's [2] study indicated that noise levels reduced by 2 to $3 \mathrm{~dB}$ at humps and $1 \mathrm{~dB}$ at the midpoint between 2 humps, which corresponded with speed reductions ranging from 5 to $14 \mathrm{~km} / \mathrm{h}$. A graph is comparing the noise levels for locations at and near the hump with predicted 'before' levels showed that the levels were lowest at the hump.

However, the noise levels can also increase near humps due to rapid acceleration and deceleration (Hidas, Weerasekera and Dunne [3]; Wewalwala and Sonnadara [4]. Wewalwala and Sonnadara's [4] study indicated that LAeq was highest as the vehicles approached $20 \mathrm{~m}$ after the road hump, with heavy vehicles and three-wheelers found to be the highest contributors to the noise levels. The study by Lee, Joo, Oh and Choi [5] also demonstrated that the impacts of road humps could also vary greatly with type, geometry, location and spacing. They also concluded that the road humps of $3 \mathrm{~m}$ and $4 \mathrm{~m}$ width resulted in the highest vehicle acceleration rates and noise levels due to the abrupt changes in speed. Also, Bendtsen and Larsen [2] conducted a social survey to assess the annoyance rate among those living 20-30m away from road humps and those living farther away. The respondents were asked if they were annoyed by the traffic noise while inside their residences with the windows closed. At the roads with $60 \mathrm{~km} / \mathrm{h}$ speed limit, $43 \%$ of those living near humps reported being annoyed or very annoyed as compared to $13 \%$ respondents living far from the road hump. The result shows 
that the installation of road humps can increase noise annoyance for the residents. Thus it is indicated that despite the speed and noise reductions as discussed above, road humps may not necessarily help improve the living condition of residential areas.

\section{Site Background}

Three residential areas were selected for this study, which was Keramat, Setiawangsa, and Putrajaya. The locations of all three areas are shown in Figure 1.

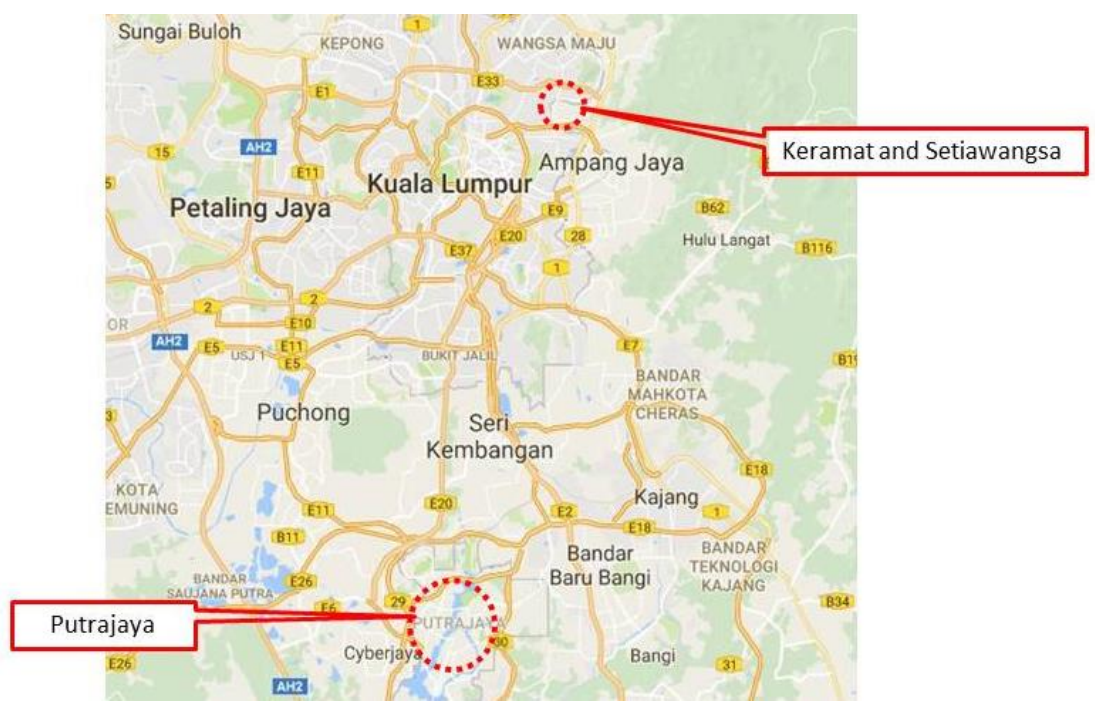

Fig. 1: Location of Keramat, Setiawangsa, and Putrajaya.

Two roads were selected in each area to assess the effect of road humps on vehicle speeds and surrounding noise levels. Table 1 lists the roads and the characteristics of the road humps selected for this study. The common criteria were that the roads were located in areas that were predominantly residential, and serve mostly localized traffic.

Table 1: Characteristics of Selected Road Humps.

\begin{tabular}{|c|c|c|c|c|c|}
\hline Road & Hump & Height & Width & Length & Spacing \\
\hline \multirow{2}{*}{$\begin{array}{l}\text { Jalan } \mathrm{P} 11 \mathrm{H} / 1 \\
\text { (Putrajaya) }\end{array}$} & $\mathrm{A}$ & $90 \mathrm{~mm}$ & $3.7 \mathrm{~m}$ & \multirow[t]{2}{*}{$6.1 \mathrm{~m}$} & \multirow[t]{2}{*}{$60 \mathrm{~m}$} \\
\hline & B & $70 \mathrm{~mm}$ & $3.8 \mathrm{~m}$ & & \\
\hline \multirow{2}{*}{$\begin{array}{l}\text { Jalan P11D } \\
\text { (Putrajaya) }\end{array}$} & $\mathrm{A}$ & $60 \mathrm{~mm}$ & $2 \mathrm{~m}$ & \multirow[t]{2}{*}{$12.8 \mathrm{~m}$} & \multirow[t]{2}{*}{$38 \mathrm{~m}$} \\
\hline & $\mathrm{B}$ & $60 \mathrm{~mm}$ & $2 \mathrm{~m}$ & & \\
\hline \multirow{2}{*}{$\begin{array}{l}\text { Persiaran Setiawangsa } \\
\text { (Setiawangsa) }\end{array}$} & $\mathrm{A}$ & $80 \mathrm{~mm}$ & $3.2 \mathrm{~m}$ & \multirow[t]{2}{*}{$11.9 \mathrm{~m}$} & \multirow[t]{2}{*}{$92 \mathrm{~m}$} \\
\hline & $\mathrm{B}$ & $60 \mathrm{~mm}$ & $3.4 \mathrm{~m}$ & & \\
\hline \multirow{2}{*}{$\begin{array}{l}\text { Jalan Setiawangsa } 21 \\
\text { (Setiawangsa) }\end{array}$} & A & $60 \mathrm{~mm}$ & $3.5 \mathrm{~m}$ & \multirow{2}{*}{$11.2 \mathrm{~m}$} & \multirow{2}{*}{$58 \mathrm{~m}$} \\
\hline & $\mathrm{B}$ & $50 \mathrm{~mm}$ & $2.7 \mathrm{~m}$ & & \\
\hline \multirow{2}{*}{$\begin{array}{l}\text { Jalan AU1C/1 } \\
\text { (Keramat) }\end{array}$} & A & $30 \mathrm{~mm}$ & $1.7 \mathrm{~m}$ & \multirow[t]{2}{*}{$5.6 \mathrm{~m}$} & \multirow[t]{2}{*}{$78 \mathrm{~m}$} \\
\hline & B & $30 \mathrm{~mm}$ & $1.5 \mathrm{~m}$ & & \\
\hline \multirow{2}{*}{$\begin{array}{l}\text { Jalan Keramat } \\
\text { (Keramat) }\end{array}$} & $\mathrm{A}$ & $50 \mathrm{~mm}$ & $3.5 \mathrm{~m}$ & \multirow[t]{2}{*}{$8.5 \mathrm{~m}$} & \multirow[t]{2}{*}{$70 \mathrm{~m}$} \\
\hline & $\mathrm{B}$ & $50 \mathrm{~mm}$ & $3 \mathrm{~m}$ & & \\
\hline
\end{tabular}

\section{Methodology}

Systematic sampling was used to identify the sample vehicles for speed measurements. The speed of moving vehicles passing the road was measured by using radar guns (Stalker Lidar XS). A total of six points for speed measurement were selected, as shown in Figures 2 and 3. The measurement of speed involved cars, motorcycles, lorries, vans and buses. 
Simultaneously, two Cirrus Optimus Green noise level meters were used to measure noise produced by the moving traffic at the abovementioned six points. The data was collected for a minimum of 8 hours and maximum of 12 hours, with the rainy weather as a limitation during the data collection period. Due to the limitation in equipment, the noise level and speed survey could not be conducted for all six points consecutively. This issue was addressed by conducting the survey at two points per day, for a total of three days per site with the assumption that traffic along the residential roads are localized and would thus be relatively similar throughout the three days. The sequence was as follows: Day 1: P5 and P6, Day 2: P2 and P3, Day 3: P1 and P4.

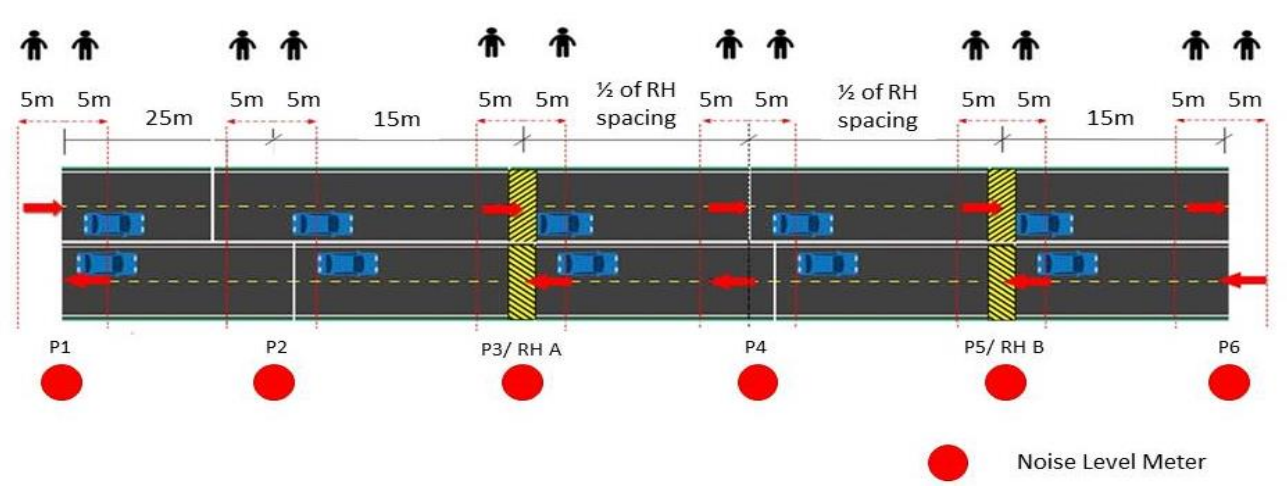

Fig. 2: Location of Points and Data Collection Setup.

The questionnaire survey was divided into three sections. Section A asked on the residents' perceptions and satisfaction of existing conditions; Section B focused on the residents' perceptions regarding the effectiveness of the existing traffic calming measures, and Section $\mathrm{C}$ requested information on the respondents' background including employment characteristics, their period of residence in the residential area and type of tenure. A 5-point Likert scale was used, with one denoting Strongly Disagree/ Extremely Unsatisfied, and five denoting Strongly Agree/ Extremely Satisfied. However, due to the lower responses in several categories, the scale was combined into three: Unsatisfied, Neutral and Satisfied.

The survey was conducted in November 2015 at Keramat, Setiawangsa, and Putrajaya. The sample sizes for each area were determined according to the number of houses in the selected residential parcels and then calculated based on Krejcie and Morgan [6]. The sample sizes for Keramat, Setiawangsa, and Putrajaya, were determined to be 269, 273 and 269 respectively. Out of the total sample size, 478 completed questionnaires were collected with a response rate of 58.9 percent. However, the response rates for Setiawangsa and Putrajaya were considerably lower $(40.3 \%$ and $58.3 \%$ respectively) compared to Keramat $(78.4 \%)$. The disparity is due to residents' reluctance to partake in the survey, particularly in Setiawangsa.

\section{Change in Noise Levels and Traffic Speed at Road Humps}

The average noise level was measured at all six points to assess the trend throughout the traffic calming scheme. Table 3 shows the LAeq variation in the selected sites, while a summary of the average vehicle speeds at the selected road humps is shown in Table 4.

Table 3: LAeq (P1-P6) along Selected Roads.

\begin{tabular}{|c|c|c|c|c|c|c|}
\hline \multirow{2}{*}{ LOCATION } & \multicolumn{6}{|c|}{ NOISE LEVEL/ LAeq (dB) } \\
\hline & P1 & $\mathrm{P} 2$ & P3 & P4 & P5 & P6 \\
\hline Jalan AU1C/1 & 64.6 & 65.8 & 64.7 & 64.3 & 64.4 & 65.3 \\
\hline Jalan Keramat & 70.5 & 70.2 & 70.8 & 70.3 & 70.8 & 72.6 \\
\hline Persiaran Setiawangsa & 73.8 & 64.2 & 63.5 & 63.5 & 62.9 & 63.4 \\
\hline Jln Setiawangsa 21 & 63.9 & 58.3 & 60.2 & 61.9 & 60.2 & 60.4 \\
\hline Jalan P11H/1 & 58.0 & 55.2 & 55.3 & 56.5 & 54.2 & 53.3 \\
\hline Jalan P11D & 56.9 & 57.9 & 59.0 & 57.7 & 58.6 & 58.8 \\
\hline
\end{tabular}


Table 4: Average Vehicle Speeds before, at and after Selected Humps ( $\mathrm{km} / \mathrm{h})$.

\begin{tabular}{|c|c|c|c|c|c|}
\hline Road & Hump & Direction & $\begin{array}{c}\text { Before } \\
\text { Hump }(\mathrm{km} / \mathrm{h})\end{array}$ & $\begin{array}{c}\text { At Hump } \\
(\mathrm{km} / \mathrm{h})\end{array}$ & $\begin{array}{c}\text { After } \\
\text { Hump } \\
(\mathrm{km} / \mathrm{h}) \\
\end{array}$ \\
\hline \multirow[t]{4}{*}{ Jalan P11H/1 } & \multirow[t]{2}{*}{ A } & In & 18.4 & 15.9 & 23.9 \\
\hline & & Out & 26.1 & 16.7 & 17.9 \\
\hline & \multirow[t]{2}{*}{$\mathrm{B}$} & In & 23.9 & 17.9 & 18.6 \\
\hline & & Out & 21.1 & 17.2 & 26.1 \\
\hline \multirow[t]{4}{*}{ Jalan P11D } & \multirow[t]{2}{*}{ A } & In & 21.8 & 20.2 & 24.1 \\
\hline & & Out & 32.1 & 20.2 & 21.9 \\
\hline & \multirow[t]{2}{*}{ B } & In & 27.4 & 17.1 & 21.8 \\
\hline & & Out & 21.9 & 18.8 & 21.5 \\
\hline \multirow{4}{*}{$\begin{array}{l}\text { Persiaran } \\
\text { Setiawangsa }\end{array}$} & \multirow[t]{2}{*}{ A } & In & 33.8 & 20.2 & 31.4 \\
\hline & & Out & 31.1 & 18.3 & 25.5 \\
\hline & \multirow[t]{2}{*}{ B } & In & 31.4 & 18.1 & 20.7 \\
\hline & & Out & 28.1 & 20.7 & 31.1 \\
\hline \multirow{4}{*}{$\begin{array}{l}\text { Jalan } \\
\text { Setiawangsa } \\
21\end{array}$} & \multirow[t]{2}{*}{ A } & In & 27.5 & 17.5 & 21.6 \\
\hline & & Out & 26.2 & 18.2 & 22.9 \\
\hline & \multirow[t]{2}{*}{ B } & In & 21.6 & 18.1 & 20.8 \\
\hline & & Out & 22.4 & 18.8 & 26.2 \\
\hline \multirow[t]{4}{*}{ Jalan AU1C/1 } & \multirow[t]{2}{*}{$\bar{A}$} & In & 29.7 & 22.3 & 26.8 \\
\hline & & Out & 22.4 & 18.3 & 29.6 \\
\hline & \multirow[t]{2}{*}{ B } & In & 22.4 & 22.3 & 29.7 \\
\hline & & Out & 22.4 & 22.3 & 29.7 \\
\hline \multirow[t]{4}{*}{ Jalan Keramat } & \multirow[t]{2}{*}{ A } & In & 26.8 & 24.7 & 24.5 \\
\hline & & Out & 28.1 & 23.5 & 23.2 \\
\hline & \multirow[t]{2}{*}{$\mathrm{B}$} & In & 24.5 & 21.9 & 23.6 \\
\hline & & Out & 28.0 & 23.0 & 28.1 \\
\hline
\end{tabular}

There was a wide variation in the vehicle speed reductions, ranging from $0.1 \mathrm{~km} / \mathrm{h}$ (Jalan AU1C/1 Hump B) to 13.6km/h (Persiaran Setiawangsa Hump A). The disparity can be attributed to the difference in hump dimensions (refer to Table 2). Another example is Jalan P11H/1 Hump A. Despite its height of 90mm and width of 3.7mm; the average speed reduction was only $2.5 \mathrm{~km} / \mathrm{h}$. It can be attributed to the effect of an intersection located less than $20 \mathrm{~m}$ away from Hump A, which was observed to alter the vehicle speeds before the hump.

Similarly, the average speed increase after the road humps ranged from $0.7 \mathrm{~km} / \mathrm{h}$ to $11.3 \mathrm{~km} / \mathrm{h}$. However, an exception was at Jalan Keramat Hump A as the average speed reduced by a further 0.2 and $0.3 \mathrm{~km} / \mathrm{h}$ after the hump. It can be attributed to the interruptions to the traffic flow, which were primarily caused by the traffic lights and buses stopping along the road.

\section{Perception of Road Hump Effects on Traffic Noise and Vehicle Speed}

In the questionnaire survey, the respondents were asked to rank their agreement with whether existing road humps have helped improve their living environment. A similar pattern can be seen throughout all three areas: more than 50 percent of the residents agreed that road humps had improved the living environment by reducing vehicle speeds. Also, a comparison between the responses to traffic noise and vehicle speed showed that a higher percentage of respondents disagreed road humps have helped improve the traffic noise levels in their respective areas.

\subsection{Keramat}

Figure 3 indicates that when the perceptions on speed and noise reduction were compared, a higher percentage of residents did not perceive existing road humps to have reduced the noise levels. When interviewed at Jalan AU1C/1, a resident noted that motorcycles normally do not slow down at the road humps and constantly emit louder exhaust noise. 


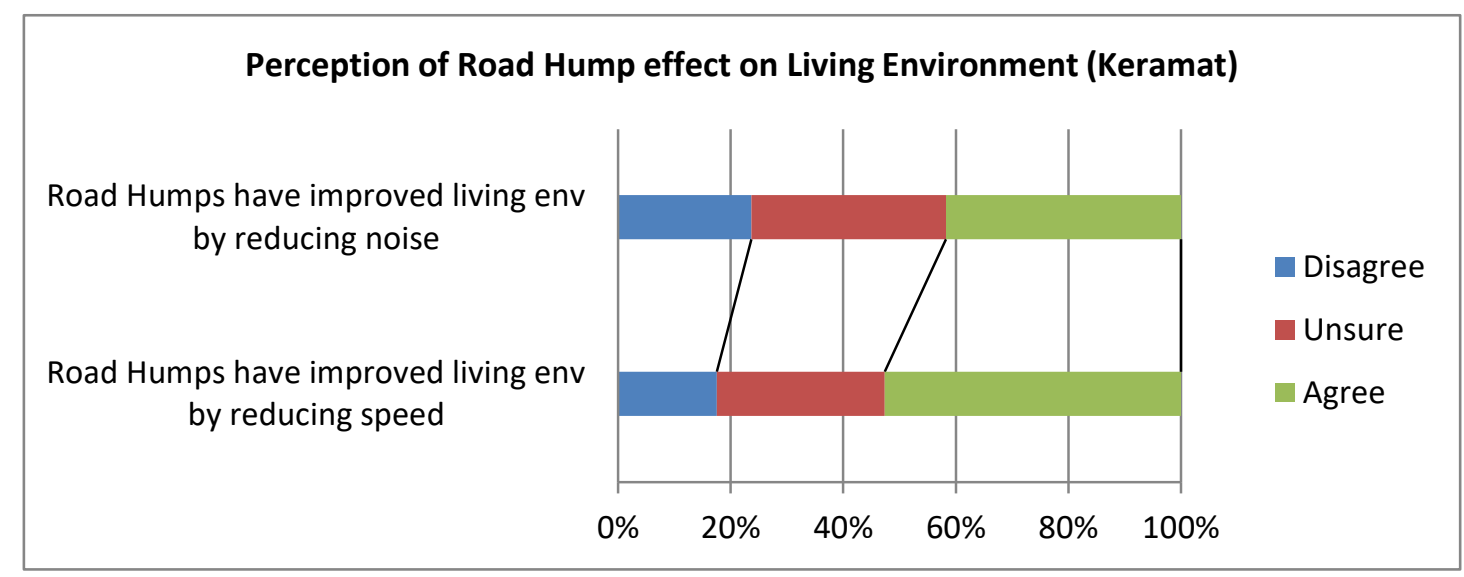

Fig. 3: Perception of Keramat Residents on Road Hump Effects.

A further assessment of Figure 3 against Figures 4 and 5 indicate that out of the three areas, Keramat had the highest percentage of respondents $(23.7 \%$ on reducing noise and $17.5 \%$ on reducing speed) not agreeing that road humps have helped improve their living environment. Jalan AU1C/1 had unusually low road humps that residents did not consider effective against motorcycles, while Jalan Keramat had high traffic volume with a high composition of motorcycles. The traffic volume along Jalan Keramat was also a combination of localized and through traffic. Also, Figure 3 indicated a lack of variation in the noise levels (LAeq) at the road humps along both Jalan AU1C/1 and Jalan Keramat. The LAeq constantly remained high along both roads, exceeding 64dB at Jalan AU1C/1 and 70dB at Jalan Keramat.

\subsection{Setiawangsa}

In comparison to Keramat, a similar pattern was observed in Setiawangsa (Figure 4). 17.3\% of the respondents disagreed that the existing road humps have improved the living environment by reducing noise levels; as compared to 7.3\% disagreeing that road humps have reduced vehicle speeds. An observation along Persiaran Setiawangsa was that activities concerning school children studying in a nearby religious school could also contribute to the noise levels. However, this was only intermittent (particularly at 5-6 pm) and may have also been due to their unfamiliarity with the survey being conducted.

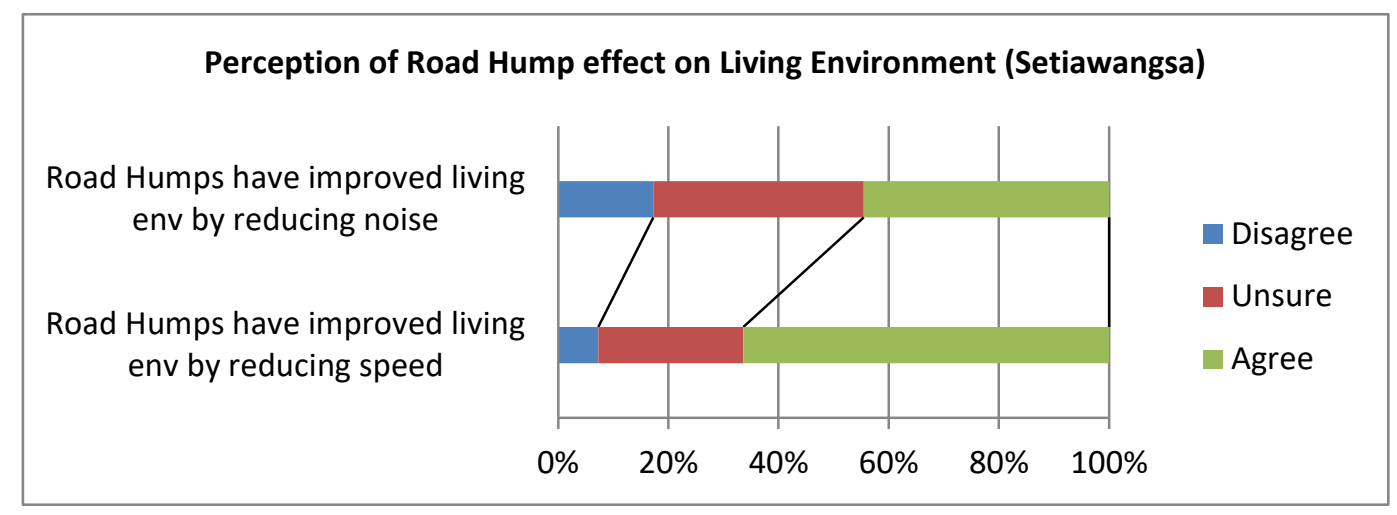

Fig. 4: Perception of Setiawangsa Residents on Road Hump Effects.

\subsection{Putrajaya}

A similar pattern as those reported in Keramat and Setiawangsa was observed in Putrajaya (Figure 5); with more people reporting their disagreement that road humps have helped reduce noise (14\%) as compared to speed (5.7\%). The percentages are lower in Putrajaya, which may be attributed to the lower traffic speeds and surrounding noise levels. The LAeq recorded along Jalan P11H/1, and Jalan P11D was slightly above the permissible noise limit of 55dB, while the traffic volume for Jalan P11H/1 was low and did not include buses. 


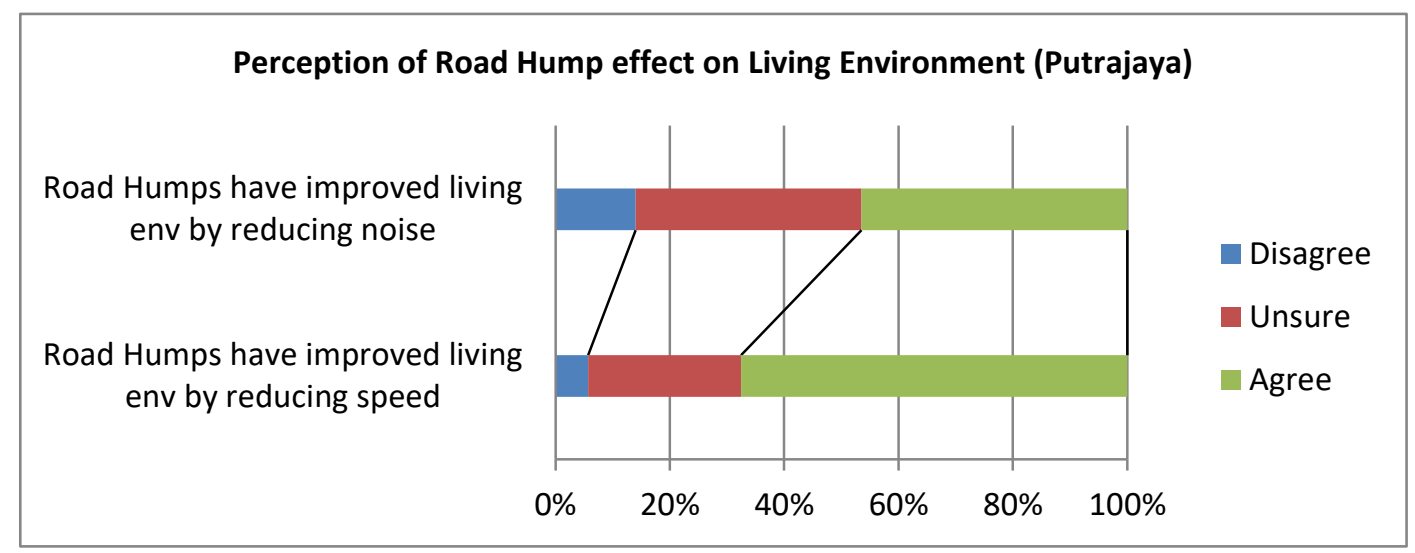

Fig. 5: Perception of Putrajaya Residents on Road Hump Effects.

\section{Binary Logistic Regression Model on Perception Regarding Traffic Noise}

Two binary logistic regression models were run to assess the effects of noise-related variables on the respondents' level of agreement on whether road humps have improved the living environment. Only two categories of the DV were considered: Agree and Otherwise (previously coded as Unsure). The Disagree category was omitted due to the low response rate. The total number of cases included was 387, with $54.3 \%$ stated that they agreed road humps had improved their living environment by reducing traffic noise. The first model included seven variables entered as IVs, which were selected based on their statistically significant correlations with the DV. The reference category was the last category, which in this case was 'Agree.' The variable 'Residential Area' was later included in the second model to assess if the effect varied across the three study areas. The reference category for this model was Putrajaya. Table 5 lists the independent variables, while the coefficients for Model 1 are as listed in Table 6.

Table 5: Noise-Related Variables to Predict Respondents’' Agreement.

\begin{tabular}{|l|l|}
\hline DV & Road Humps have Improved Living Environment by Reducing Traffic Noise \\
\hline IV & Road humps can reduce vehicle noise \\
\hline & Road humps have reduced car noise \\
\hline & Road humps have reduced motorcycle noise \\
\hline & Road humps have reduced van noise \\
\hline & Road humps have reduced lorry and bus noise \\
\hline & Road hump height is consistent \\
& $\begin{array}{l}\text { Road hump is provided where required } \\
\text { Residential Area (Model 2 only) }\end{array}$ \\
\hline
\end{tabular}

Model 1 was statistically significant, $\chi 2(14)=151.907, p=<0.0005$. The Wald statistics and the significance indicated that three variables significantly contribute to the DV $(\mathrm{p}=<0.01)$. The variables 'Road Humps have reduced Motorcycle Noise', 'Road Humps have reduced Van Noise,' 'Road Humps have reduced Bus \& Lorry Noise,' and 'Road Hump Height is Consistent' were not statistically significant predictors. The values for the Cox \& Snell and Nagelkerke R2 values ranged from 0.325 to 0.434 , which indicated that the IVs predicted $32.5 \%$ to $43.4 \%$ of the DV. The model correctly classified $76 \%$ of the cases, with sensitivity at $80.5 \%$ and specificity of $70.6 \%$.

The coefficients were all negative except 'Road Humps have reduced car noise.' However, it should be noted that $p=>0.0005$ for this variable, meaning that its contribution is not statistically different as compared to those who agreed that road humps had reduced car noise. Also, respondents that reported being unsure on whether road humps have been provided as required were 0.333 times less likely to agree that road humps have improved the living environment by reducing traffic noise. 
Table 6: Results of the Binary Logistic Regression Model 1 ( $\mathrm{n}=387)$.

\begin{tabular}{|l|c|c|c|c|c|}
\hline DV= Road Humps have Improved Living Environment by Reducing Traffic Noise \\
\hline IV & $\beta$ & SE & Wald & $p$-value & Exp(B) \\
\hline Constant & 2.337 & .277 & 71.444 & .000 & 10.355 \\
\hline RH can reduce noise & & & 25.770 & .000 & \\
\hline RH can reduce noise (1) & -2.056 & .428 & 23.090 & .000 & .128 \\
\hline RH can reduce noise (2) & -.798 & .292 & 7.466 & .006 & .450 \\
\hline RH have reduced car noise & & & 7.593 & .022 & \\
\hline RH have reduced car noise (1) & .799 & .512 & 2.436 & .119 & 2.224 \\
\hline RH have reduced car noise (2) & -.579 & .334 & 3.003 & .083 & .560 \\
\hline RH have reduced MC noise & & 1.483 & & .476 & \\
\hline RH have reduced MC noise (1) & -.039 & .456 & .007 & .932 & .962 \\
\hline RH have reduced MC noise (2) & -.397 & .342 & 1.354 & .245 & .672 \\
\hline RH have reduced van noise & & & .912 & .634 & \\
\hline RH have reduced van noise (1) & -.307 & .775 & .156 & .692 & .736 \\
\hline RH have reduced van noise (2) & -.456 & .478 & .912 & .340 & .634 \\
\hline RH have reduced bus \& lorry noise & & & 3.682 & .159 & \\
\hline RH have reduced bus \& lorry noise \\
(1)
\end{tabular}

Note: $\mathrm{RH}=$ Road Hump, $\mathrm{MC}=$ motorcycle

The coefficients for Model 2 are as listed in Table 7. The logistic regression model was statistically significant, $\chi^{2}(16)=152.947, p=<0.0005$ and the variables that significantly predict the DV was the same as in Model 1. 'Residential Area' was also not a statistically significant predictor. A very slight improvement was reported for the Cox \& Snell and Nagelkerke $\mathrm{R}^{2}$ values in Model 2, which indicated the prediction of the DV to range from $32.6 \%$ to $43.6 \%$. The model correctly classified $77.0 \%$ of the cases, with sensitivity at $80.5 \%$ and specificity of $72.9 \%$. 
Table 7: Results of the Binary Logistic Regression Model 2 ( $n=387)$.

\begin{tabular}{|l|l|l|l|l|l|}
\hline DV= Road Humps have Improved Living Environment by Reducing Traffic Noise \\
\hline IV & $\beta$ & SE & Wald & $p$-value & Exp(B) \\
\hline Constant & 2.311 & .329 & 49.317 & .000 & 10.081 \\
\hline RH can reduce noise & & & 25.900 & .000 & \\
\hline RH can reduce noise (1) & -2.088 & .433 & 23.201 & .000 & .124 \\
\hline RH can reduce noise (2) & -.789 & .293 & 7.238 & .007 & .454 \\
\hline RH have reduced car noise & & & 8.189 & .017 & \\
\hline RH have reduced car noise (1) & .847 & .514 & 2.713 & .100 & 2.333 \\
\hline RH have reduced car noise (2) & -.609 & .337 & 3.263 & .071 & .544 \\
\hline RH have reduced MC noise & & 1.556 & & .459 & \\
\hline RH have reduced MC noise (1) & -.072 & .457 & .025 & .875 & .931 \\
\hline RH have reduced MC noise (2) & -.416 & .344 & 1.465 & .226 & .660 \\
\hline RH have reduced van noise & & & .937 & .626 & \\
\hline RH have reduced van noise (1) & -.303 & .786 & .149 & .700 & .738 \\
\hline RH have reduced van noise (2) & -.463 & .479 & .937 & .333 & .629 \\
\hline RH have reduced bus \& lorry noise & & & 3.175 & .204 & \\
\hline RH have reduced bus \& lorry noise (1) & -.1 .281 & .760 & 2.841 & .092 & .278 \\
\hline RH have reduced bus \& lorry noise (2) & -.639 & .487 & 1.719 & .190 & .528 \\
\hline RH height is consistent & & & .762 & .683 & \\
\hline RH height is consistent (1) & -.121 & .434 & .078 & .781 & .886 \\
\hline RH height is consistent (2) & -.273 & .313 & .762 & .383 & .761 \\
\hline RH is provided where required & & & 14.589 & .001 & \\
\hline RH is provided where required (1) & -.955 & .565 & 2.858 & .091 & .385 \\
\hline RH is provided where required (2) & -1.154 & .308 & 13.988 & .000 & .316 \\
\hline Residential Area & & & 1.035 & .596 & \\
\hline Residential Area (1) & .163 & .309 & .277 & .599 & 1.177 \\
\hline Residential Area (2) & -.188 & .355 & .280 & .597 & .829 \\
\hline-2 Log likelihood & 380.732 & & & & \\
\hline Model Chi-square & 152.947 & & & .000 & \\
\hline Cox \& Snell R square & .326 & & & & \\
\hline Nagelkerke R square & .436 & & & & \\
\hline
\end{tabular}

Note: $\mathrm{RH}=$ Road Hump, $\mathrm{MC}=$ motorcycle

The coefficients in the second model were largely similar to the first one indicating low variance between both models, and that perception remained the same in all areas. Similar to the first model, respondents who disagreed that road humps have reduced car noise were 2.333 times more likely to agree that the existing road humps have improved the living environment by reducing traffic noise; though again this bore no statistically significant difference in contribution with those who agreed. In comparison, those who did not agree that road humps can reduce noise levels were 0.124 times less likely to agree that existing road humps have improved their living environment by reducing noise levels. As stated earlier, the different residential areas were found to not significantly contribute to the model's predictive power $(p>0.005)$. Hence no further models were run to assess the respondents' perceptions of traffic noise levels according to residential areas.

\section{Conclusion}

This paper provided a descriptive analysis of the impacts of road humps on Malaysian residential living environments. It briefly discussed the changes in average noise levels and average vehicle speeds. A large variation in speed reductions and a lack of variation in LAeq at road humps were due to the differences in hump dimensions and locations. The findings showed that road humps are effective in controlling vehicle speeds but less effective in reducing traffic noise levels, which were also reflected in the respondents' perceptions gathered from the questionnaire survey. The 
binary logistic regressions showed little variation after controlling the influence of the different residential areas, and residential areas were deemed not to be significant in predicting the respondents' perceptions on existing road humps.

\section{Acknowledgements}

The authors would like to express their sincere gratitude to MOSTI for providing the research grant for this project.

\section{References}

[1] P. Abbott, M. Taylor, R. Layfield, "The effects of traffic calming measures on vehicle and traffic noise," in Traffic Engineering \& Control, 1997.

[2] H. Bendtsen, L.E. Larsen. "Noise and nuisance from road humps," in $29^{\text {th }}$ International Congress and Exhibition on Noise Control Engineering, France, 2000.

[3] P. Hidas, K. Weerasekera, M. Dunne, "Negative effects of mid-block speed control devices and their importance in the overall impact of traffic calming on the environment," Transportation Research Part D, vol. 3, no. 1, pp. 41-50, 1998.

[4] S. N. Wewalwala, and D. U. J. Sonnadara, "Traffic noise enhancement due to speed bumps," Sri Lankan Journal of Physics, vol. 12, pp. 1-6, 2011.

[5] G. Lee, S. Joo, C. Oh, K. Choi, "An evaluation framework for traffic calming measures in residential areas," Transportation Research Part D, 25, pp. 68-76, 2013.

[6] R. V. Krejcie, D. W. Morgan, "Determining sample size for research activities," Educational and Psychological Measurement, vol. 30, pp. 607-610, 1970. 